\title{
Phenotypic and Genotypic Characteristics of Antimicrobial and Disinfectant Resistance of Gram-negative Bacteria Involved in Early Broiler Chick Mortality
}

\author{
Mohammed Iraqi ${ }^{1}$, Soad A Nasef ${ }^{1}$ and Mona El-Enbaawy ${ }^{2}$ \\ ${ }^{1}$ Animal Health Research Institute, Dokki, Egypt; ${ }^{2}$ Microbiology Department, Faculty of Veterinary Medicine, Cairo \\ University, Egypt \\ *Corresponding author: dr_mona_1@ @hotmail.com
}

\begin{abstract}
\begin{tabular}{llll}
\hline Article History: 20-213 & Received: 08-Oct-20 & Revised: 08-Dec-20 & Accepted: 17-Dec-20 \\
\hline
\end{tabular}
\section{ABSTRACT}

One of the most challenges facing the poultry industry in Egypt is the early mortality among broiler chicks during the first ten days of the rearing cycle, especially which caused by antimicrobial resistant Gram-negative bacteria .This study was conducted for the determination of the prevalence of Gram-negative bacteria involved in early mortality among broiler chicks. Antibiogram profile and antibiotic and disinfectant resistance genes were also performed. Five hundred samples (liver, yolk sac, cecum, spleen, and heart) from freshly dead affected chicks were cultured on different media for isolation of causative agents.by conventional and serological methods. PCR was used for detection of resistance genes. The Bacteriological examination revealed the presence of Salmonella spp., E. coli, and $P$. aeruginosa in the percentages of 23, 25 and 8\%, respectively. Single and mixed infections were observed as 41 , and 7\%, respectively. $86.9 \%$ of Salmonella serovars were resistant to colistin sulphate, $48 \%$ of E. coli strains showed resistance against norfloxacin, and $87.5 \%$ of $P$. aeruginosa showed resistance against florfenicol. The $m c r l$ gene was found in $86.9 \%$ of all Salmonella serovar, $q \mathrm{nrS}$ gene was detected in $16 \%$ of E. coli, and floR gene was present in $100 \%$ of $P$. aeruginosa isolates. PCR screening for qacEDl revealed that all bacterial isolates under test were positive. It was concluded that results of current study assert the existence $m c r l$, qnrS, floR, and qacEDl genes among (Salmonella spp., E. coli, and P. aeruginosa) which were isolated from early aged broiler dead chicks; that represents a high risk on the poultry industry in Egypt.
\end{abstract}

Key words: Dead broiler chicks Salmonella serovars, E. coli serotypes, P. aeruginosa, mcrl, qnrS, floR, qacEDl. (C)2020 IJVS - All Rights Reserved

\section{INTRODUCTION}

Early chick mortality is one of the most vital problems of the chicken industry. Flocks of poultry are often reared under strong hygienic environments with elevated levels of antimicrobials for disease prevention and diagnosis, as well as boosting growth. Pathogens which are resistant to antimicrobials can lead to treatment failure, this results in economic losses (Nhung et al. 2017). Infections due to antibiotic-resistant microorganisms are hard, and now and again not possible to treat and can cause mortality (Alaali and Thani 2020).

Omphalitis and yolk sac infection were considered as the major causes for the high mortalities during the first week of life in broiler farms. Several bacteria agents have been isolated and identified such as E. coli, Salmonella, Staphylococcus, Proteus, and Pseudomonas (Hassan et al. 2017). A widespread of antibiotics' resistance in
Salmonella is of great concern (Cailhol et al. 2006; Dorgham et al. 2019). From day-old chicks and eggs, different percentages of bacterial (E. coli and Pseudomonas spp.) strains showed resistance against different classes of antibiotics (Nazer et al. 2006). Multidrug resistance $P$. aeruginosa is highly pathogenic to chicks of 1-10 days old (Kebede 2010).

Colistin represents one of the few available drugs for treating infections caused by resistant Enterobacteriaceae. As such, the spread of the colistin resistance gene mcr-1 poses a significant public health threat, requiring global monitoring and surveillance (Wang et al. 2018). Fluoroquinolones are considered as one of the most frequently applied antimicrobials' groups, particularly in poultry. Resistance towards fluoroquinolones came about because of the effects of some genes such as $g y r \mathrm{~A}$ and $q n r \mathrm{~S}$ which hinder the synthesis of bacterial DNA (Talukdar et al. 2013). Florfenicol is a by-product of

Cite This Article as: Iraqi M, Nasef SA and El-Enbaawy M, 2021. Phenotypic and genotypic characteristics of antimicrobial and disinfectant resistance gram-negative bacteria involved in early broiler chick mortality. International Journal of Veterinary Science 10(2): 129-134. https://doi.org/10.47278/journal.ijvs/2020.033 
chloramphenicol which is prescribed mainly for the treatment of animal illnesses. the main gene that induces florfenicol resistance is floR which can distribute between bacteria of the same and specific species or genera via a horizontal gene spread (Lu et al. 2018).

The presence of bacterial resistance against many drugs emphasizes the need to prevent diseases in chicks by the hygiene. The remaining line of protection for the chicken production must probably be the usage of disinfectants as Quaternary Ammonium Compounds which is probably regularly utilized in environments where antibiotics are used (Hegstad et al. 2010). Many reviews reported a molecular relationship between QACs genes and antibiotic resistance in some pathogenic bacteria (Buffet-Bataillon et al. 2012).

Here we focus on the prevalence of antimicrobial-and disinfectant resistant-Gram-negative bacteria involved in early mortality in broiler chicks. Antibiogram profile and antibiotic and disinfectant resistance genes were also performed.

\section{MATERIALS AND METHODS}

A whole of five hundred samples (liver, yolk sac, cecum, spleen, and heart) 5 from each farm was collected aseptically. These samples were from 100 broiler farms suffered from weakness, depression, diarrhea, respiratory manifestation and omphalitis, during the first 10 days of the rearing period.

\section{Microbiological Examination}

One gram from each sample was inoculated in a tube containing $9 \mathrm{ml}$ of $1 \%$ buffered peptone water. and incubated at $37^{\circ} \mathrm{C}$ for $18-24$ hours. The incubated samples were inoculated onto MacConkey agar plates. Then developed colonies depended on macroscopic and microscopic appearance, were subcultured on appropriate differential media.

Expected Salmonella. P. aeruginosa and E. coli colonies were streaked on brilliant green agar and xyloselysine-deoxycholate (XLD) agar (Oxoid, Pseudomonas cetrimide agar medium (Oxoid) and E.M.B agar plates, respectively. And then aerobically incubated at $37^{\circ} \mathrm{C}$ for 18-24hrs. Suspected colonies were subjected to biochemical analysis as described by ISO 6579-1 (2007) and Quinn et al. (2013).

The biochemically identified Salmonella isolates were subjected to serological identification according to Grimont and Weill (2007). E. coli strains were serotyped by the usage of rapid diagnostic $E$. coli antisera Set 1 containing monovalent and polyvalent $\mathrm{O}$ antisera (Denka Seiken Company, LTD-Japan).

\section{Antimicrobial Susceptibility Testing}

An antimicrobial sensitivity testing was achieved by the disc diffusion technique, in steps with the standards and results interpretation defined with the aid of the National Committee for Clinical Laboratory Standards (NCCLS 2018). Eight antimicrobials discs (Oxoid, Hampshire, U okay) represented to six antimicrobial groups have been used as shown in Table 3.

\section{PCR for Resistance Genes Detection}

The DNA extraction from samples has been completed through the usage of the QIA-amp DNA Mini kit (Qiagen, GmbH, Germany). Oligonucleotide primers have specific sequences (Metabion, Germany), targeted genes and their amplified fragment sizes are shown in Table 1. These primers were applied in a $25 \mu 1$ reaction including 12.5 $\mu$ l of Emerald Amp Max PCR Mastermix (Takara, Japan), $1 \mu$ l of separate primer of 20 picomole concentrations, $4.5 \mu \mathrm{l}$ of water and $6 \mu \mathrm{l}$ of the template DNA. Cycle conditions for different primers are shown in Table 2. In a Biometra thermal cycler, the PCR outcomes had been separated by way of electrophoresis in $1.5 \%$ agarose gel (ABgene). One hundred base pair and 100600 base pair deoxyribonucleic-acid ladders (Qiagen, USA) decide the fragment sizes were used. The gel became pictured with the aid of a documentation device and the records became stored via a computer software program.

\section{Statistical Analysis}

Statistics evaluation had been carried out using Statistical Package for Social Sciences edition 22 for windows. A Chi-square test has been used to determine the presence of an association between antimicrobial resistance and the presence of resistance genes at $\mathrm{P} \leq 0.05$ (IBM Corp. Released 2013).

\section{RESULTS}

\section{Microbiological Examination and the Incidence of Bacterial Isolation}

As shown in Table 3, the microbiological examination of the collected samples revealed Gramnegative bacteria (Salmonella, E. coli and P. aeruginosa) with different percentages.

\section{Antibiogram Pattern of Isolated Gram-Negative Bacteria}

Table 3 clarified the antibiogram pattern of Gramnegative bacteria isolates against 8 antibiotics related to 6 antibiotic groups.

PCR Results for Detection of Antibiotics and Quaternary Ammonium Compounds Resistance Genes Genotypically, Table 4 and Fig. 1-6 showed the results of detection of resistance genes ( $\mathrm{mcrl}$, qnrS, and floR) in Salmonella, E. coli, and P. aeruginosa isolates, respectively as well as qacEDl for all isolates under test.

\section{DISCUSSION}

Excessive use of antibiotics and disinfectants would lead to the elevation of antibiotic and disinfectant resistance (Eid et al. 2016). In order to study the phenotypic and genotypic characterization of some antibiotic-resistant Gram-negative bacteria responsible for early mortality in broiler chicks, this work was designated. In the present study the isolated bacteria were Salmonella, E. coli, and P. aeruginosa with 23, 25 and $8 \%$, respectively. In Egypt, many studies (EL-Sawah et al 2016; El-Tawab et al. 2017; Saad et al. 2017; Ibrahim et al. 2019) considered $E$. coli as the most common 
Int J Vet Sci, 2021, 10(2): 129-134.

Table 1: Oligonucleotide primers sequences

\begin{tabular}{|c|c|c|c|c|}
\hline Isolates & Target gene & Sequences $\left(5^{\prime} \rightarrow 3^{\prime}\right)$ & Amplified product size & References \\
\hline $\begin{array}{l}\text { Salmonella, E. coli, } \\
\text { and P. aeruginosa }\end{array}$ & Qac-EDl & $\begin{array}{l}\text { F: TAA GCC CTA CACAAA TTG GGA GAT AT } \\
\text { R: GCC TCC GCA GCG ACT TCCACG }\end{array}$ & $362 \mathrm{bp}$ & $\begin{array}{l}\text { Chuanchuen et al. } \\
\text { (2007) }\end{array}$ \\
\hline $\begin{array}{l}\text { Salmonella } \\
\text { Serovars }\end{array}$ & mcrl & $\begin{array}{l}\text { F: CGGTCAGTCCGTTTGTTC } \\
\text { R: CTTGGTCGGTCTGTAGGG }\end{array}$ & $308 \mathrm{bp}$ & $\begin{array}{l}\text { Newton-Foot et al. } \\
\text { (2017) }\end{array}$ \\
\hline E. coli serotypes & $q n r S$ & $\begin{array}{l}\text { F: ACGACATTCGTCAACTGCAA } \\
\text { R: TAAATTGGCACCCTGTAGGC }\end{array}$ & 516 bp & $\begin{array}{l}\text { (Robicsek et al. } \\
\text { (2006) }\end{array}$ \\
\hline P. aeruginosa & floR & $\begin{array}{l}\text { F: TTTGGWCCGCTMTCRGAC } \\
\text { R: SGAGAARAAGACGAAGAAG }\end{array}$ & 494 bp & $\begin{array}{l}\text { Doublet et al. } \\
(2003)\end{array}$ \\
\hline
\end{tabular}

Table 2: Cycling conditions of the different primers

\begin{tabular}{lccccccc}
\hline Isolates & $\begin{array}{c}\text { Target } \\
\text { gene }\end{array}$ & $\begin{array}{c}\text { 1ry } \\
\text { denaturation }\end{array}$ & $\begin{array}{c}2 \text { ry } \\
\text { denaturation }\end{array}$ & Annealing & Extension & $\begin{array}{c}\text { No. of } \\
\text { cycles }\end{array}$ & $\begin{array}{c}\text { Final } \\
\text { extension }\end{array}$ \\
\hline Salmonella, E. coli, \& & QacEDl & $94^{\circ} \mathrm{C}$ & $94^{\circ} \mathrm{C}$ & $58^{\circ} \mathrm{C}$ & $72^{\circ} \mathrm{C}$ & 35 & $72^{\circ} \mathrm{C}$ \\
P. aeruginosa & & $5 \mathrm{~min}$ & $30 \mathrm{~s}$ & $40 \mathrm{~s}$ & $40 \mathrm{~s}$ & $10 \mathrm{~min}$ \\
Salmonella & $m c r 1$ & $94^{\circ} \mathrm{C}$ & $94^{\circ} \mathrm{C}$ & $60^{\circ} \mathrm{C}$ & $72^{\circ} \mathrm{C}$ & 35 & $72^{\circ} \mathrm{C}$ \\
Serovars & & $5 \mathrm{~min}$ & $30 \mathrm{~s}$ & $30 \mathrm{~s}$ & $30 \mathrm{~s}$ & $7 \mathrm{~min}$ \\
E. coli serotypes & $q n r S$ & $94^{\circ} \mathrm{C}$ & $94^{\circ} \mathrm{C}$ & $55^{\circ} \mathrm{C}$ & $72^{\circ} \mathrm{C}$ & 35 & $72^{\circ} \mathrm{C}$ \\
& & $5 \mathrm{~min}$ & $30 \mathrm{~s}$ & $40 \mathrm{~s}$ & $45 \mathrm{~s}$ & $70 \mathrm{~min}$ \\
P. aeruginosa & \multirow{2}{*}{ floR } & $94^{\circ} \mathrm{C}$ & $94^{\circ} \mathrm{C}$ & $50^{\circ} \mathrm{C}$ & $72^{\circ} \mathrm{C}$ & 35 & $72^{\circ} \mathrm{C}$ \\
& & $5 \mathrm{~min}$ & $30 \mathrm{~s}$ & $40 \mathrm{~s}$ & $45 \mathrm{~s}$ & & $10 \mathrm{~min}$ \\
\hline
\end{tabular}

Table 3: Antibiogram sensitivity and resistance pattern of isolated Gram-negative bacteria

\begin{tabular}{llcccccc}
\hline \multirow{2}{*}{ Antimicrobial group } & Antimicrobial & \multicolumn{2}{c}{ Salmonella serovars } & \multicolumn{2}{c}{ E. coli } & \multicolumn{2}{c}{ P. aeruginosa } \\
\cline { 2 - 7 } & discs & S \% & R \% & S \% & R \% & S \% & R \% \\
\hline Aminopenicillins & AMC 30 & 91.3 & 4.3 & 76 & 12 & 50.0 & 25.0 \\
& AMP 10 & 34.8 & 65.2 & 4 & 80 & 12.5 & 87.5 \\
Aminoglycosides & S 10 & 34.8 & 13.0 & 12 & 48 & 37.5 & 25.0 \\
& N 30 & 43.5 & 43.5 & 8 & 56 & 37.5 & 50.0 \\
Polypeptide Abcs & CT 10 & 13.1 & 86.9 & 20 & 80 & 62.5 & 37.5 \\
Florfenicol & FFO 30 & 78.3 & 21.7 & 48 & 52 & 12.5 & 87.5 \\
Fluoroquinolones & NOR 10 & 65.2 & 26.1 & 44 & 48 & 75.0 & 12.5 \\
Tetracyclines & DO 30 & 47.8 & 47.8 & 24 & 48 & 12.5 & 62.5 \\
\hline
\end{tabular}

Delete \% from all values: (Amoxicillin-clavulanic acid) AMP 10 (Ampicillin), S 10 (Streptomycin), N 30 (Neomycin), CT 10 (Colistin sulphate), FFO 30 (Florfenicol), NOR 10 (Norfloxacin), DO 30 (Doxycycline), S=Sensitive, R=Resistance.

Table 4: Distribution of antibiotics and QACs resistance genes by PCR

\begin{tabular}{|c|c|c|c|c|c|c|}
\hline \multirow[t]{2}{*}{ Target genes } & \multicolumn{2}{|c|}{ Salmonella + ve serovars } & \multicolumn{2}{|c|}{ E. coli +ve serotypes } & \multicolumn{2}{|c|}{ +ve $P$. aeruginosa } \\
\hline & No & $\%$ & No & $\%$ & No & $\%$ \\
\hline QacED1 & $23 / 23$ & 100 & $25 / 25$ & 100 & $8 / 8$ & 100 \\
\hline mcrl & $20 / 23$ & 86.9 & & & & \\
\hline$q n r S$ & & & $4 / 25$ & 16 & & \\
\hline floR & & & & & $8 / 8$ & 100 \\
\hline
\end{tabular}

contaminant of chicken yolk sacs. Other isolates from yolk sac were $P$. aeruginosa, Escherichia coli, Salmonella spp., Coagulase Negative staphylococci (CNS), S. aureus, P. mirabilis, K. pneumonia, Streptococcus spp. and E. aerogenes. On the other hand, Shahjada et al. (2017) isolated E. coli, Salmonella, and Staphylococcus with percentages of 28,38 and $34 \%$, respectively from broiler chicks suffered from omphalitis in Bangladesh.

Amare et al. (2013) find E. coli with the highest percentage followed by $S$. aureus and $P$. mirabilis from chicks in Ethiopia. On the other hand, Shahat et al. (2019) reported that the incidence of Pseudomonas species in broiler chicks (1-10 days) suffered from diarrhea, yellowish nasal secretion, ruffled feather, and conjunctivitis from different farms was $42 \%$. Single and mixed infections were observed as the most predominant single infections were in E. coli $(19 \%)$, followed by Salmonella (16\%). The most predominant mixed infections were Salmonella and E. coli (5\%). Other mixed infections were noticed in low percentages; $E$. coli and Salmonella in $(1 \%)$ and $P$. aeruginosa, E. coli, and Salmonella (1\%). EL-Sawah et al. (2016) stated that the diseased chicks, harbored bacterial strains with an incidence of 62.5 and $28.2 \%$ as single and mixed infections, respectively.

In the present study, the serotyping of $E$. coli isolates recovered from the dead chicks revealed $12 \mathrm{E}$. coli serotypes with the highest percentage for O78 (24\%). Followed by $\mathrm{O} 2$, and $\mathrm{O} 158$ (each of 12\%) and $\mathrm{O} 128$ and O1 were (each of $8 \%$ ). On the other hand, the lowest serotypes percent were for O145, O144, O125, O119, $\mathrm{O} 26$, and $\mathrm{O} 146$ (each of 4\%). Serotypes O78, and $\mathrm{O} 2$ constitute $80 \%$ of sickness-inflicting avian pathogenic $E$. coli (APEC) globally (Dziva and Stevens 2008). E. coli O146, O2 and O26 were recorded by EL-Sawah et al. (2016), Saad et al. (2017) and Ibrahim et al. (2019) as serogroups recovered from chicks suffered from omphalitis and newly hatched chicks in Egypt.

In our study, out of 23 Salmonella isolates recovered from diseased chicks $S$. Enteritidis possessed the highest percentage of isolation followed by Salmonella Kentucky and Salmonella Typhimurium. S. Enteritidis, S. Typhimurium, S. Kingston, S. Senftenberg, S. Blegdam, S. Emek, S. Inganda, S. Molade, and S. Apyeme 
Int J Vet Sci, 2021, 10(2): 129-134.

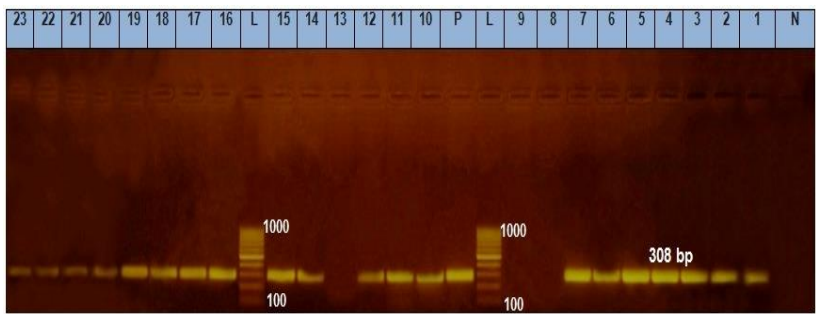

Fig. 1: Agarose gel electrophoresis of PCR: Amplification profile to monitor $\mathrm{mcrl}$ gene of 23 Salmonella isolates at 308 bp: Lane L: 100-1000 bp DNA ladder. N: Negative control, P: Positive control. Lane: 1-7, 10-12, 14, 15 and 16-23 were positive for $m c r 1$ gene. Lane 1, 17: S. tamale; Lane 2, 6: S. inganda; Lane 3, 7, 12, 14, 18, 20: S. enteritidis; Lane 4: $S$. molade; Lane 5, 15, 19: S. typhimurium; Lane 22: S. kentucky; Lane 11: S. labadi; Lane16, 23: S. takoradi; Lane 21: S. papuana; Lane 10: Untypable.

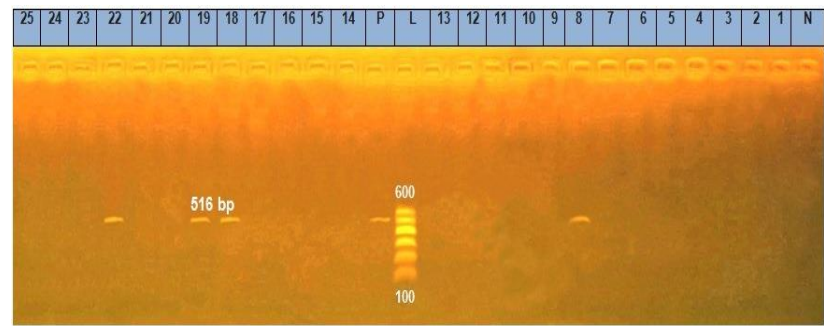

Fig. 2: Agarose gel electrophoresis of PCR: Amplification products $(516 \mathrm{bp}$ ) to monitor $q n r S$ gene in 25 of E. coli isolates. Lane L: 100-600 bp DNA ladder. N: Negative control, P: Positive control. Lane: $8,18,19$, and 22 were positive for $q n r S$ gene. Lane 8: O1: H7, Lane 18: O2: H6, Lane 19: O26, Lane 22: 0146 .

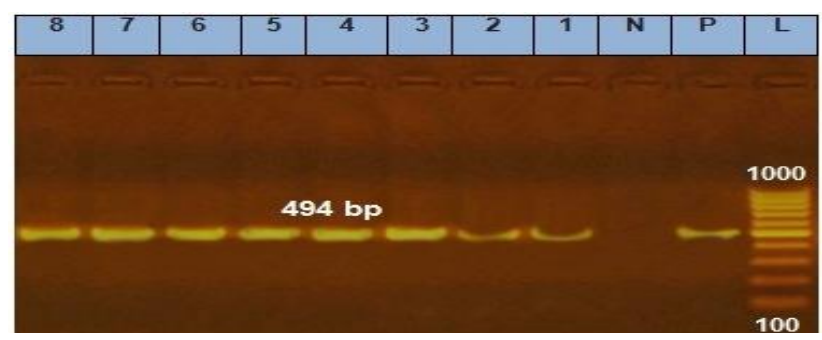

Fig. 3: Agarose gel electrophoresis of PCR: Amplification profile of floR gene of 8 P. aeruginosa isolates at $494 \mathrm{bp}$ : Lane L: $100-1000$ bp DNA ladder. N: Negative control, P: Positive control. Lane: (1-8) were positive for the floR gene.

were recovered by El-Sawah et al. (2016), El-sharkawy et al. (2017) and Hassan et al. (2017) from chicks suffering from omphalitis and from different organs of 1-day to1week old birds.

Antibiotics are profusely administered for therapeutic and prophylaxis purposes in the veterinary field (Dandachi et al. 2018). The resistance of a microorganism to numerous antibiotic groups outcomes in decrease within the medication efficacy of infectious illnesses resulting from those microorganisms (Alaali and Thani 2020).

In our study, as shown in Table 3, 86.9\% of Salmonella were resistant to colistin sulphate while $48 \%$ of $E$. coli was resistant to norfloxacin and $87.5 \%$ of $P$. aeruginosa isolates showed resistance against florfenicol. In another report, $P$. aeruginosa strains isolated from 216 yolk sacs of baby chicks were resistant to florfenicol (ElSawah et al. 2016). All P. aeruginosa isolates recovered

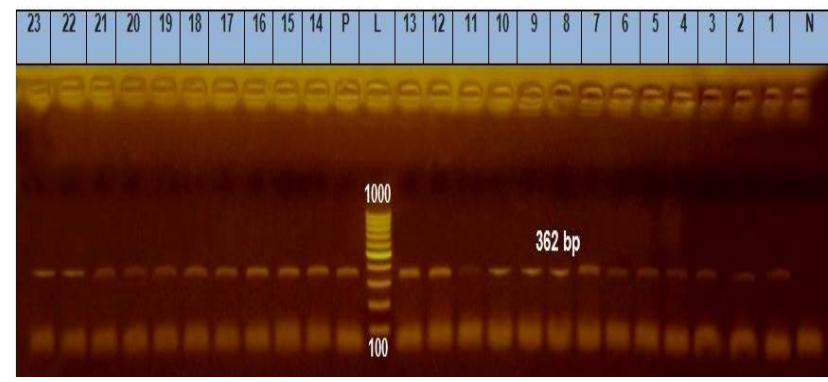

Fig. 4: Agarose gel electrophoresis of PCR: Amplification profile of QacED1 gene at 362 bp for Salmonella isolates: Lane L: 100-1000 bp DNA ladder. N: Negative control, P: Positive control. Lane: (1-23) were positive for QacED1 gene. Lane 1, 17: S. tamale; Lane 2, 6: S. inganda; Lane 3, 7, 12, 14, 18, 20: S. enteritidis; Lane 4: S. molade; Lane 5, 15, 19: S. typhimurium; Lane 8, 9, 13, 22: S. kentucky; Lane 11: S. labadi; Lane16, 23: S. takoradi; Lane 21: S. papuana; Lane 10: Untypable.

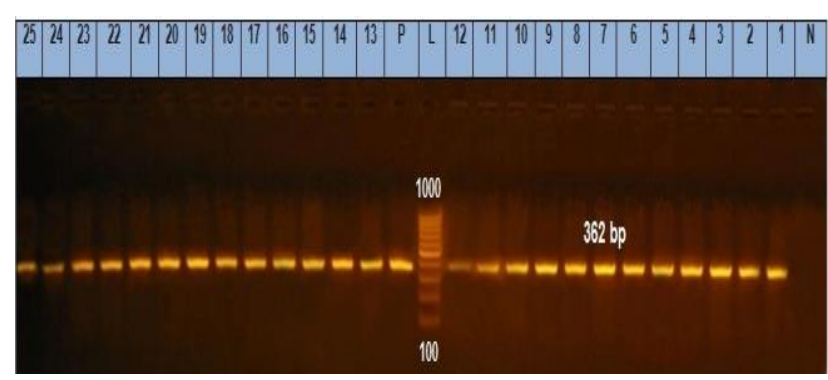

Fig. 5: Agarose gel electrophoresis of PCR: Amplification profile of QacEDl gene at 362 bp for E. coli. isolates: Lane L: 100-1000 bp DNA ladder. N: Negative control, P: Positive control. Lane: (1 -25) were positive for QacED1 gene. Lane 1, 18: O2:H6; Lane 2, 4, 9: O158; Lane 3: O145; Lane 5, 10, 15 , 20, 21, 23: O78; Lane 6, 8: O1:H7, Lane 7: O1:H6, Lane 11: O144; Lane 12, 13, 25: O91; Lane 14: O125; Lane 16: O119; Lane 17, 24: O128; Lane 19: O26; Lane 22: O146.

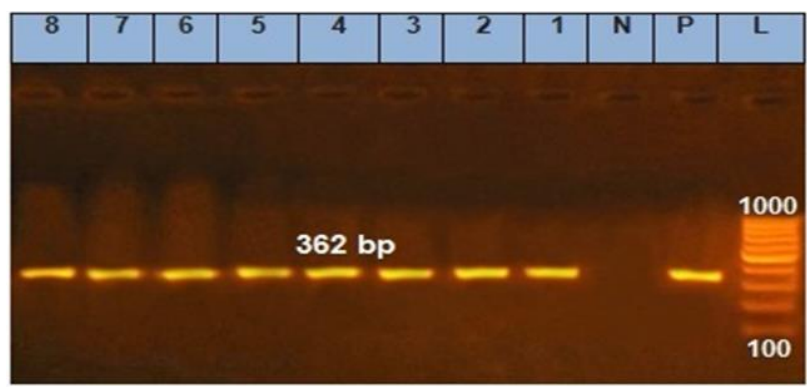

Fig. 6: Agarose: gel electrophoresis of PCR: Amplification profile of QacED1 gene at 362 bp for $P$. aeruginosa isolates Lane L: 100-1000 bp DNA ladder. N: Negative control, P: Positive control. Lane:(1 -8) were positive for QacEDl gene.

from the liver, heart, and yolk sacs of 50 samples of baby chicks were $100 \%$ resistant to ampicillin (Shahat et al 2019).

Antimicrobial-resistant microorganisms are basically a result of natural choice. Genetic differences in bacteria might also bring mutations, which expected to be effective for their viability even though the presence of the antimicrobials (Exner et al. 2017). Screening the presence of $m c r l$, qnrS, and floR genes in Salmonella, E. coli, and $P$. aeruginosa isolates, respectively by PCR technique revealed that $m c r 1$ gene was found in $86.9 \%$ of all isolated Salmonella serovar except 3 serovars of $S$. 
Kentucky (Fig. 1). The researches focusing on the $m c r-1$ gene-carrying $E$. coli, and $k$. pneumonia isolates are frequent, on the other hand, the researches on the emergence and molecular features of the $m c r-1$ gene in Salmonella spp. are still inadequate (Lu et al. 2019). The $m c r$ genes have also been detected in $S$. Enterica, even though more scarcely than in E. coli. Many mcr-carrying $S$. Enterica strains display multidrug resistance forms, with several genes allowing resistance to tetracyclines, beta-lactams which include cephalosporins, streptomycin, sulfamethoxazole/ trimethoprim, and quinolones. Moreover, S. typhimurium is the maximum widespread serotype containing $\mathrm{mcr}$ genes (Borowiak et al. 2017). In the current work, it is interesting to note that other Salmonella serovars (S. Tamale, S. Inganda, S. Molade, S. Labadi, S. Takoradi, S. Papuana, S. Kentucky) also harbored the gene $m c r 1$. Resistance towards norfloxacin is taken place commonly due to activities of genes products' such as qnrS (Talukdar et al. 2013). In our study, qnrS gene was detected in 4/25 (16\%) of E. coli (O1, O2, 26 \& O146).

In the present work, floR gene was found in $100 \%$ of $P$. aeruginosa isolates. The floR gene and its analogs have particularly been recognized in Gram-negative bacteria, while the different resistance genes have especially been found in Gram-positive microorganism (Lu et al. 2018).

Disinfectants have been used with a carelessness that leading to the adaptation of bacteria and augmenting the spread of resistant bacteria (Loughlin et al. 2002). Quaternary Ammonium Compounds also are supposed to destruct the outer membrane of Gram-negative microorganism, consequently enhancing their own uptake (McDonnell and Denver 1999). In our study, qacED1 gene was found in all Gram-negative strains (Salmonella, Escherichia coli, and Pseudomonas aeruginosa) with the same $100 \%$ percentage, these results agreed with results reported by various workers (Nabil et al. 2019; Shahat et al. 2019) as they detected qacEDI gene between E. coli, Salmonella, and P. aeruginosa isolates in $100 \%$ case. Between the Gram-negative bacteria, QACs resistance genes are frequently associated with plasmid-mediated class 1 integrons that possess a variety of antimicrobial resistance genes.

QACs resistance genes are combined decisively with genes that promote resistance to Sulphonamides, Trimethoprim Chloramphenicol, Aminoglycosides, and Beta- lactams (Zhao et al. 2012; Schill et al. 2017).

\section{Conclusion}

There is a direct link between illnesses due to antimicrobial-resistant Gram-negative microorganisms and early death in broiler chicks. It is fundamental to enhance the surveillance of antibiotic and disinfectant resistance levels in our chicken farms to stop the unfold of resistant microbes.

Author's Contribution: MEE and SAN designed the study and provided precious feedback and ideas throughout the course of the study; MI carried out the lab analyses, performed statistical analyses, and prepared the manuscript with the supervision and technical help of MEE. All authors approved the final version of the manuscript.

\section{REFERENCES}

Alaali Z and Thani AS, 2020. Patterns of antimicrobial resistance observed in the Middle East: Environmental and health care retrospectives. Science of The Total Environment 10: 140089. https://doi.org/10.1016/j. scitotenv.2020.140089

Amare A, Amin AM, Shiferaw A, Nazir S and Negussie H, 2013. Yolk sac infection (omphalitis) in Kombolcha poultry farm, Ethiopia. American-Eurasian Journal of Scientific Research 8: 10-14. https://doi.org/10.5829/idosi.aejsr.2013. 8.1.65108

Borowiak M, Fischer J, Hammerl JA, Hendriksen RS, Szabo I and Malorny B, 2017. Identification of a novel transposonassociated phosphoethanolamine transferase gene, $\mathrm{mcr}-5$, conferring colistin resistance in d-tartrate fermenting Salmonella enterica subsp. enterica serovar Paratyphi B. Journal of Antimicrobial Chemotherapy 72: 3317-3324. https://doi.org/10.1093/jac/dkx327

Buffet-Bataillon S, Le Jeune A, Le Gall-David S, BonnaureMallet M and Jolivet-Gougeon A, 2012. Molecular mechanisms of higher MICs of antibiotics and quaternary ammonium compounds for Escherichia coli isolated from bacteremia. Journal of Antimicrobial Chemotherapy 1: 2837-2842. https://doi.org/10.1093/jac/dks321

Cailhol J, Lailler R, Bouvet P, La Vieille S, Gauchard F, Sanders $\mathrm{P}$ and Brisabois A, 2006. Trends in antimicrobial resistance phenotypes in non-typhoid Salmonellae from human and poultry origins in France. Epidemiology \& Infection 134 171-178. https://doi.org/10.1017/S0950268805004863

Chuanchuen R, Khemtong S and Padungtod P, 2007. Occurrence of qacE/qacEDl genes and their correlation with class 1 integrons in Salmonella enterica isolates from poultry and swine. Southeast Asian Journal of Tropical Medicine and Public Health 38: 855-862.

Corp IB, 2013. IBM SPSS statistics for windows, version 22.0. Armonk, NY: IBM Corp. http://www.sciepub.com/ reference/278397

Dandachi I, Sokhn ES, Dahdouh EA, Azar E, El-Bazzal B, Rolain JM and Daoud Z, 2018. Prevalence and characterization of multi-drug-resistant gram-negative bacilli isolated from Lebanese poultry: A nationwide study. Frontiers in Microbiology 23: 550. https://doi.org/10.3389/ fmicb.2018.00550

Dorgham SM, Hedia RH, Arafa AA, Khairy EA and Kandil MM, 2019. Antibiotic resistance pattern and biofilm genes of different Salmonella serotypes isolated from chicken samples. International Journal of Veterinary Science 8 324-328.

Doublet B, Lailler R, Meunier D, Brisabois A, Boyd D, Mulvey MR, Chaslus-Dancla E and Cloeckaert A, 2003. Variant Salmonella genomic island 1 antibiotic resistance gene cluster in Salmonella enterica serovar Albany. Emerging Infectious Diseases 9: 585-591. https://doi.org/10.3201/ eid0905.020609

Dziva F and Stevens MP, 2008. Colibacillosis in poultry: unravelling the molecular basis of virulence of avian pathogenic Escherichia coli in their natural hosts. Avian Pathology 37: 355-366. https://doi.org/10.1080/ 03079450 802216652

Eid HI, Algammal AM, Nasef SA, Elfeil WK and Mansour GH, 2016. Genetic variation among avian pathogenic E. coli strains isolated from broiler chickens. Asian Journal of Animal and Veterinary Advances 11: 350-356. https://doi.org/10.3923/ajava.2016.350.356

EL-Sawah AA, M Dahshan AL, Nasef SA, El-Nahass ES and Nayel AI, 2016. Characterization of E. coli and Salmonella spp. isolates associated with omphalitis in baby chicks. Journal of Veterinary Medical Research 23: 61-70. 
El-Sharkawy H, Tahoun A, El-Gohary AE, El-Abasy M, ElKhayat F, Gillespie T, Kitade Y, Hafez HM, Neubauer H and El-Adawy H, 2017. Epidemiological, molecular characterization and antibiotic resistance of Salmonella enterica serovars isolated from chicken farms in Egypt. Gut Pathogens 9: Article \# 8. https://doi.org/10.1186/s13099017-0157-1

El-Tawab A, Ashraf A, El-Hofy FI, Nasef SA and Ibrahim OA, 2017. Prevalence of eaeA and qacEAl genes in Escherichia coli isolated from omphalitis in baby chicks. Benha Veterinary Medical Journal 32: 184-192. https://doi.org/ 10.21608/bvmj.2017.31206

Exner M, Bhattacharya S, Christiansen B, Gebel J, GoroncyBermes P, Hartemann P, Heeg P, Ilschner C, Kramer A, Larson E and Merkens W, 2017. Antibiotic resistance: What is so special about multidrug-resistant Gram-negative bacteria? GMS Hygiene and Infection Control 12: 1-24. https://doi.org/10.3205/dgkh000290

Grimont PAD and Weill FX, 2007. Antigenic formulae of the Salmonella serovars. $9^{\text {th }}$ Ed. WHO Collaborating Centre for Reference and Research on Salmonella, Institut Pasteur Paris, France, pp: 1-167.

Hassan HM, Nabil NM and Tawakol MM, 2017. Studies on some causes of bacterial diseases associated with early mortalities in chicks. Animal Health Research Journal 5: 218-232.

Hegstad K, Langsrud S, Lunestad BT, Scheie AA, Sunde M and Yazdankhah SP, 2010. Does the wide use of quaternary ammonium compounds enhance the selection and spread of antimicrobial resistance and thus threaten our health? Microbial Drug Resistance 1: 91-104. https://doi.org/ 10.1089/mdr.2009.0120

Ibrahim WA, Marouf SA, Erfan AM, Nasef SA and El Jakee JK, 2019. The occurrence of disinfectant and antibiotic-resistant genes in Escherichia coli isolated from chickens in Egypt. Veterinary World 12: 141-145. https://doi.org/10.14202/ vetworld.2019.141-145

ISO, 2007. International Organization for Standardization. ISO 6579:2002/Amd 1:2007 Detection of Salmonella spp. in animal faeces and in environmental samples from the primary production stage, amendment 1 , annex $\mathrm{D}$ in Microbiology of food and animal feeding stuffs. Horizontal method for the detection of Salmonella Spp. International Organization for Standardization, Geneva, Switzerland. https://www.iso.org/obp/ui/\#iso:std:iso:6579

Kebede F, 2010. Pseudomonas infection in chickens. Journal of Veterinary Medicine and Animal Health 2: 55-58. https://doi.org/10.5897/JVMAH.9000021

Loughlin MF, Jones MV and Lambert PA, 2002. Pseudomonas aeruginosa cells adapted to benzalkonium chloride show resistance to other membrane-active agents but not to clinically relevant antibiotics. Journal of Antimicrobial Chemotherapy 49: 631-639. https://doi.org/10.1093/jac/ 49.4.631

Lu J, Quan J, Zhao D, Wang Y, Yu Y and Zhu J, 2019. Prevalence and molecular characteristics of $m c r-1$ gene in Salmonella typhimurium in a tertiary hospital of Zhejiang Province. Infection and Drug Resistance 12: 105-110. https://doi.org/10.2147/IDR.S190269

Lu J, Zhang J, Xu L, Liu Y, Li P, Zhu T, Cheng C, Lu S, Xu T, Yi H and Li K, 2018. Spread of the florfenicol resistance floR gene among clinical Klebsiella pneumoniae isolates in China. Antimicrobial Resistance \& Infection Control 7: Article number 127. https://doi.org/10.1186/s13756$\underline{0180415-0}$

McDonnell G and Russell AD, 1999. Antiseptics and disinfectants: activity, action, and resistance. Clinical Microbiology Reviews 12: 147-179. https://doi.org/ 10.1128/CMR.12.1.147
Nabil NM and Yonis AE, 2019. Isolation of Salmonella characterized by biofilm formation and disinfectant resistance from broiler chickens. Alexandria Journal for Veterinary Sciences 62: 26-36. https://doi.org/10.5455/ ajvs. 57274

National Committee for Clinical Laboratory Standards NCCLS, 2018. M-100 Performance Standards for Antimicrobial susceptibility testing. https://clsi.org/media/2663/m100ed29

Nazer AH, Dadras H and Eskandari S, 2006. Aerobic bacteria isolated from eggs and day-old chicks and their antibacterial resistance in Shiraz, Iran. Iranian Journal of Veterinary Research 7: 20-30. https://doi.org/10.22099/ IJVR.2006.2659

Newton-Foot M, Snyman Y, Maloba MR and Whitelaw AC, 2017. Plasmid-mediated $m c r-1$ colistin resistance in Escherichia coli and Klebsiella spp. clinical isolates from the Western Cape region of South Africa. Antimicrobial Resistance \& Infection Control 6: 1-7. https://doi.org/ 10.1186/s13756-017-0234-8

Nhung NT, Chansiripornchai N and Carrique-Mas JJ, 2017. Antimicrobial resistance in bacterial poultry pathogens: a review. Frontiers in Veterinary Science 4: Article 126. https://doi.org/10.3389/fvets.2017.00126

Quinn JP, Carter ME, Markey BK and Carter GR, 2013. Clinical Veterinary Microbiology. $2^{\text {nd }}$ Ed. Harcourt Publishers Ltd., London, UK; pp: 61-63.

Robicsek A, Strahilevitz J, Sahm DF, Jacoby GA and Hooper DC, 2006. qnr prevalence in ceftazidime resistant Enterobacteriaceae isolates from the United States. Antimicrobial Agents and Chemotherapy 50: 2872-2874. https://doi.org/10.1128/AAC.01647-05

Saad ZA, Nasef SA, Elhariri M, Elhelw R and Ezzeldeen N, 2017. Resistance patterns associated with bacterial pathogens causing omphalitis in baby chicks. Bioscience Research 14: 845-851.

Schill F, Abdulmawjood A, Klein G and Reich F, 2017. Prevalence and characterization of extended-spectrum $\beta$ lactamase (ESBL) and AmpC $\beta$-lactamase producing Enterobacteriaceae in fresh pork meat at processing level in Germany. International Journal of Food Microbiology 257: 58-66. https://doi.org/10.1016/j.ijfoodmicro.2017.06. 010

Shahat HS, Mohamed H, Al-Azeem A, Mohammed W and Nasef SA, 2019. Molecular detection of some virulence genes in Pseudomonas aeruginosa Isolated from chicken embryos and broilers with regard to disinfectant resistance. SVU-International Journal of Veterinary Sciences 2: 52-70. https://doi.org/10.21608/SVU.2019.12365.1011

Shahjada Z, Khalid H and Monowarul I, 2017. Bacteria causing omphalitis in newly hatched chicks from broiler and layer flocks and their antibiotic profiles. International Journal of Natural and Social Sciences 4: 73-81.

Talukdar PK, Rahman M, Rahman M, Nabi A, Islam Z, Hoque MM, Endtz HP and Islam MA. 2013. Antimicrobial resistance, virulence factors and genetic diversity of Escherichia coli isolates from household water supply in Dhaka, Bangladesh. PLoS ONE 8: 1-8. https://doi.org/ 10.1371/journal.pone.0061090

Wang R, van Dorp L, Shaw LP, Bradley P, Wang Q, Wang X, Jin L, Zhang Q, Liu Y, Rieux A and Dorai-Schneiders T, 2018. The global distribution and spread of the mobilized colistin resistance gene $\mathrm{mcr}$ - 1 . Nature Communications 9: 1-9. https://doi.org/10.1038/s41467-018-03205-z

Zhao WH, Chen G, Ito R, Kimura $\mathrm{S}$ and $\mathrm{Hu}$ ZQ, 2012. Identification of a plasmid-borne blaIMP-11 gene in clinical isolates of Escherichia coli and Klebsiella pneumoniae. Journal of Medical Microbiology 61: 246-251. https://doi.org/10.1099/jmm.0.035626-0 